\title{
PERENCANAAN INTERPRETASI WISATA DI RESORT MINASA TE'NE, TAMAN NASIONAL BANTIMURUNG BULUSARAUNG
}

\section{(Planning of Tourism Interpretation at Minasa Te'ne Resort Bantimurung Bulusaraung National Park)}

\author{
Nardy Noerman Najib \\ Departemen Kehutanan, Fakultas Kehutanan UNANDA, Palopo91921 \\ Email :nardy.najib@yahoo.com
}

\begin{abstract}
Maros-Pangkep karstis the second largest karst area in the world after China. Most of this area was found in Bantimurung Bulusaraung National Park. So this place has potential attraction to be visited. One of interesting object is the prehistoric cave in Biraeng Village, Pangkep. Visitor who came expecting acquire deep knowledge aftertouristactivity. It can be realized through the activities of interpretation. Based on the reason, this research was conducted with the aim to draw up planning of natural interpretationin Minasa Te'ne Resort. So it can help managers to develop nature tourism activities in particular interpretation. The theme of interpretation activities are Natural and Historical Tourist of Minasa Te'ne. The location was at a Resort Minasa Te'ne, Biraeng Village, Pangkep. The object of natural resources is water pool that the water comes from natural cave of Leang Londrong. Whereas the object of historical interpretation are Leang Caddia, Bubbuka, Lambuto,Lompoa, Kassi, Pattenung and Kajuara. There are three plans which include the planning interpretation, activity plan, units and the assignment plan.
\end{abstract}

Keywords :Bantimurung Bulusarauang National Park, ecotourism, interpretation

\begin{abstract}
Abstrak
Kawasan Karst Maros-Pangkep merupakan kawasan karst terluas kedua di dunia setelah karst alam di China. Sebagian besar kawasan ini terdapat di dalam Taman Nasional Bantimurung Bulusaraung. Dengan adanya potensi tersebut kawasan ini memiliki daya tarik yang potensial untuk dikunjungi. Salah satu objek yang menarik dikunjungi adalah barisan goa prasejarah di Desa Biraeng Kabupaten Pangkep. Namun pengunjung yang datang mengharapkan memperoleh pengetahuan yang mendalam setelah melakukan kegiatan wisata. Hal tersebut dapat diwujudkan melalui kegiatan interpretasi. Berdasarkan alasan tersebut maka penelitian bertujuan untuk menyusun rencana interpretasi alam di kawasan wisata Resort Minasa Te'ne Taman Nasional Bantimurung Bulusaraung. Manfaat penelitian ini yakni dapat membantu pengelola dalam upaya mengembangkan wisata alam khususnya kegiatan interpretasi. Tema kegiatan interpretasi di kawasan ini adalah Wisata Alam dan Sejarah Minasa Te'ne. Lokasi kegiatan berada pada Resort Minasa Te'ne Kelurahan Biraeng dan Desa Panaikang Kecamatan Minasa Te'ne Kabupaten Pangkep. Obyek interpretasi sumberdaya alam berupa kolam permandian alami yang airnya berasal dari dalam goa Leang Londong. Sedangkan objek interpretasi sejarah yang dapat ditemui antara lain Leang Bubbuka, Leang Caddia, Leang Lambuto, Leang Lompoa, Leang Kassi, Leang Kajuara dan Leang Pattenung. Terdapat tiga rencana yang mencakup perencanaan interpretasi yakni rencana satuan, rencana kegiatan, dan rencana penugasan.
\end{abstract}

Kata kunci : ekowisata, interpretasi, Taman Nasional Bantimurung Bulusaraung 


\section{PENDAHULUAN}

Taman Nasional Bantimurung Bulusaraung termasuk dalam wilayah Kabupaten Maros dan Kabupaten Pangkajene (Pangkep), Propinsi Sulawesi Selatan.Kawasan Karst Maros-Pangkep merupakan kawasan karst terluas kedua di dunia setelah karst alam di China. Pada kaki dan lereng bukit karst tower terdapat ratusan gua dalam berbagai bentuk dan ukuran serta banyak menyimpan berbagai bentuk peninggalan sejarah dan purbakala, berbagai jenis flora dan fauna yang unik, serta memiliki fungsi sebagai salah satu pengatur tata air kawasan sekitarnya (sejarah.kompasiana). Oleh karena itu kawasan ini telah diusulkan ke UNESCO sejak tahun 2001 untuk ditetapkan sebagai Cultural World Heritage Site dan Nature World Heritage Site.

Dengan adanya potensi tersebut kawasan ini memiliki daya tarik yang potensial untuk dikunjungi.Beberapa objek wisata yang telah dikembangkan antara lain Wisata Bantimurung, Wisata Prasejarah Leang-Leang, Wisata Pattunuang Asue, Pengamatan Satwa Karaenta, Gua Vertikal Leang Puteh, Pegunungan Bulusaraung, dan Permandian Alam Leang Londrong (TN.Babul 2011). Namun selain tujuh potensi wisata tersebut, masih terdapat potensi lain yang menarik perhatian pengunjung, diantaranya barisan goa prasejarah yang terletak di Resort Minasa Te'ne, kawasan Biraeng Kabupaten Pangkep. Sebagai kawasan yang memiliki keunikan dan kekhasan, maka Pemerintah Kabupaten Pangkajene dan Kepulauan melalui Dinas Kebudayaan dan Pariwisata berupaya merencanakan pengembangan kawasan karst Pangkep tanpa merusak sumber daya yang ada agar keberadaan kawasan wisata tetap memberikan manfaat kepada masyarakat setempat.

Penelitian terkait pengembangan kawasan karst Pangkep telah dilakukan oleh
Tim FPS Karst Pangkep (2013). Penelitian tersebut merencanakan pengembangan kawasan karst sebagai daya tarik wisata bumi. Namun kegiatan tersebut perlu didukung dengan adanya kegiatan interpretasi. Menurut Sharpe (1982) dalam Heriyaningtyas (2009) pengunjung di kawasan wisata alam memerlukan kegiatan interpretasi untuk lebih menikmati aktivitas rekreasinya. Interpretasi bermakna komunikasi guna memperkaya pemahaman mereka dari suatu kebenaran fakta (McArthur 2005). Interpretasi juga memberikan kesempatan kepada pengunjung untuk mendapatkan suatu pengalaman (Carr 2004). Penelitian ini dilakukan untuk menyusun perencanaan interpretasi alam di kawasan wisata Resort Minasa Te'ne Taman Nasional Bantimurung Bulusaraung sehingga pengunjung dapat memperoleh pengetahuan lebih mendalam mengenai objek wisata yang dikunjunginya. Manfaat penelitian ini adalah membantu pengelola dalam upaya mengembangkan wisata alam khususnya kegiatan interpretasi di lokasi tersebut.

\section{METODE PENELITIAN}

Penelitian ini dilakukan di Resort Minasa Te'ne, Taman Nasional Bantimurung Bulusaraung pada bulan Februari 2014. Objek yang dikaji yakni pelaku kegiatan wisata (pengelola kawasan) dan potensi kawasan. Alat dan bahan yang digunakan meliputi peta survey potensi taman nasional, alat tulis, Global Positioning System (GPS), kamera, meteran, alat pengukur waktu, dan software ArcView GIS 3.3.

Tahapan kegiatan penelitian meliputi tahap pengumpulan data dengan studi literatur mengenai prospektus kawasan, wawancara kepada pihak balai taman nasional untuk mengetahui potensi pengunjung selama ini pada objek penelitian dan pengamatan serta pengukuran langsung di lapangan untuk mencocokkan data yang diperoleh dari studi 
Volume 1 Nomor 1 Juli 2019: 24-33

pustaka, meliputi pengamatan fauna, flora, budaya masyarakat, fenomena yang menarik dan pengamatan jalur. Tahapan selanjutnya yakni pembuatan peta interpretasi mulai dari pembuatan peta dasar kawasan hingga proses tumpang tindih objek yang berpotensi sebagai objek interpretasi.

Selanjutnya, data dan informasi yang diperoleh ditabulasi kemudian diuraikan dan dianalisis secara deskriptif meliputi sumberdaya fisik, biologi, sosial budaya masyarakat, dan pengembangan pengelola. Selain itu diuraikan juga semua sarana dan prasarana yang dibutuhkan pengunjung selama proses interpretasi. Sedangkan proses pembuatan peta interprteasi menggunakan ArcView GIS 3.3 yang menghasilkan keluaran berupa data digital, kemudian peta dikoreksi dan dilakukan pengisian koordinat Universal Transverse Mercator (UTM). Proses dilanjutkan dengan melakukan tumpang tindih antara hasil pengolahan peta dasar dengan sebaran potensi wisata maka menghasilkan peta potensi objek interpretasi (Satyatama 2008).

\section{HASIL DAN PEMBAHASAN}

Tujuan dari perencanaan interpretasi ini mengacu pada Ferry (1998) yakni mampu membantu pengelola dalam mengembangkan perencanaan jangka panjang, memberikan solusi perlindungan sumberdaya alam dan peningkatan kinerja pengelola serta memberikan solusi atas masalah sumberdaya alam. Tema kegiatan interpretasi ini adalah Wisata Alam dan Sejarah Minasa Te’ne.

\section{A. Rencana Satuan Interpretasi}

Rencana satuan interpretasi ditujukan kepadadelapan objek wisata di kawasan Resort Minasa Te'ne. Rencana tersebut meliputi lokasi, jalur interpretasi, objek interpretasi, mediayang dibutuhkan, dan sarana prasarana yang mendukung.Lokasi kegiatan interpretasi berada di Resort Minasa Te'ne Kelurahan Biraeng (Gambar 1) dan Desa Panaikang (Gambar 2) Kecamatan Minasa Te'ne Kabupaten Pangkajene dan Kepulauan. Lokasi ini dipilih karena terdapat objek wisata berupa show cave dengan lokasi yang cukup berdekatan satu dengan yang lainnya. Terdapat dua lokasi utama pada jalur interpretasi ini yakni Leang Londrong dan barisan goa Biraeng.

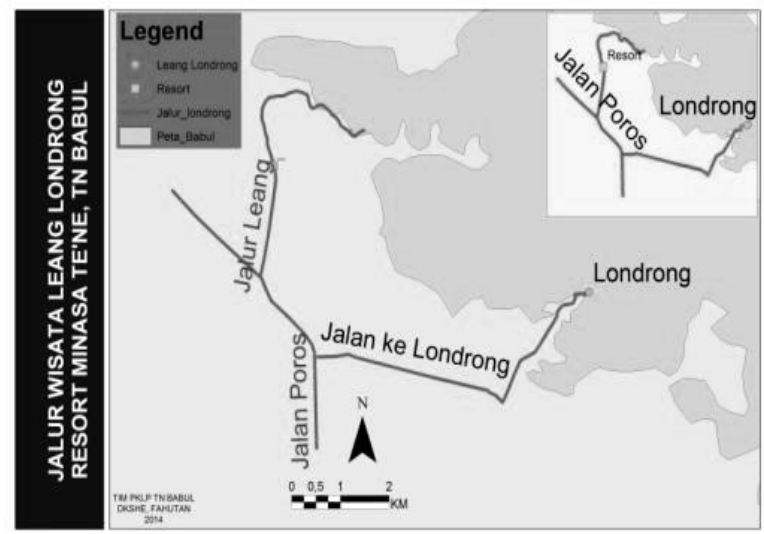

Gambar 1 Lokasi Leang Londrong di Desa Panaikang (Leang Londrong research location in Panaikang Village)

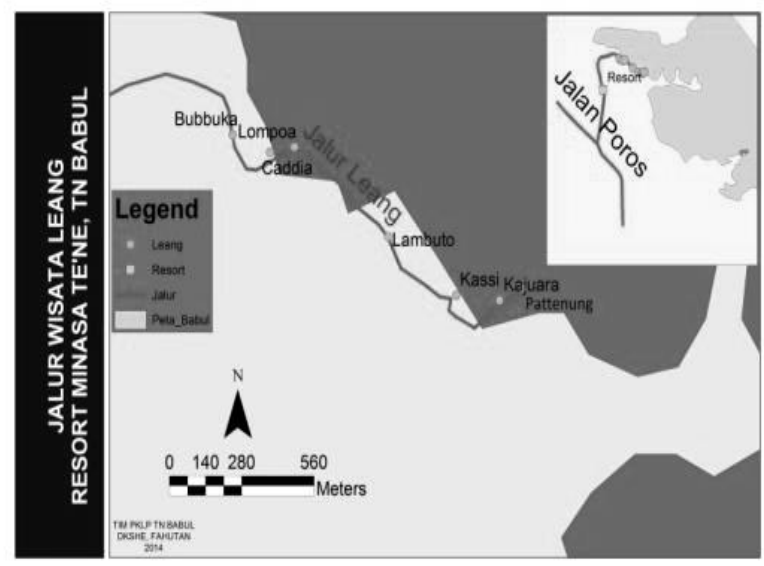

Gambar 2 Lokasi Barisan Leang di Desa Biraeng (Cave location in Biraeng Village) 
Jalur interpretasi adalah jalur khusus yang digunakan pengunjung menuju objek interpretasi. Jalur yang digunakan adalah jalur yang sudah ada yakni jalur utama menuju kawasan karst di kelurahan Biraeng dan Desa Panaikang. Kondisi jalur menuju kawasan karst di kelurahan Biraeng beraspal dengan lebar jalur tiga meter dan panjang jalur 1.5 $\mathrm{km}$. Sedangkan jalur menuju objek wisata Leang Londrong berupa jalan setapak yang dibeton dengan lebar satu meter dan panjang 512 meter. Pemilihan jalur didasarkan pada kriteria jalur interpretasi yang baik menurut Domroese dan Sterling (1999), yaitu diarahkan pada objek spektakuler yakni gua, jalan tidak licin, tidak curam, tidak tergenang, dan tidak berlumpur, jalur dilengkapi dengan rambu-rambu dan petunjuk arah yang jelas, jalur tidak lurus dan jarak antar objek tidak terlalu jauh, jalur tidak melalui komunitas tumbuhan dan satwa yang mudah terganggu, jalur dirancang untuk berbagai sarana transportasi dan pejalan kaki, serta alurnya disesuaikan dengan objek dan memperhatikan faktor kejenuhan pengunjung.Objek interpretasi adalah segala sesuatu di dalam kawasan yang digunakan sebagai objek utama dalam menyelenggarakan interpretasi. Potensi wisata di kawasan ini didominasi oleh goa, baik yang termasuk show cave maupun wild cave. Objek yang disajikan di kawasan resort Minasa Te'ne adalah objek interpretasi sumberdaya alam dan objek interpretasi sejarah. Berikut potensi delapan goa yang dijadikan objek interpretasi:

\section{Leang Londrong}

Jarak dari Kantor Seksi I Pangkep menuju Leang Londrong $10.9 \mathrm{~km}$. Akses menuju Leang Londrong melalui jalan Poros Makassar - Pangkep lalu menuju Desa Panaikang dusun Leang Londrong sejauh \pm tujuh $\mathrm{km}$ (Gambar 1).Ekosistem sepanjang jalur adalah hutan karst yang didominasi pepohonan seperti pohon pulai (Alstonia scholaris R.Br)dan pandan berduri (Pandanus sp.). Terdapat pula tebing batu, batu karang, dan sungai kecil yang terdapat di sisi jalur menuju Leang Londrong. Di sebelah kanan jalur terdapat padang penggembalan sapi milik warga.Flora yang terdapat di sepanjang jalur pada jenis pohon adalah Ficus sp., pohon mangga, pohon pulai (Alstonia scholaris), pohon jati (Tectona grandis). Sedangkan pada jenis tumbuhan bawah terdapat daun kapalkapal, jarak pagar, takokak (Solanum torvum), iles-iles, dan kunyit (Curcuma domestica). Fauna yang ditemukan antara lain Eurema sp.dan kadal batu.

Objek utama dari jalur ini adalah kolam permandian yang berada di mulut goa Leang Londrong dengan sumber air utama berasal dari dalam goa. Sepanjang jalur juga dapat ditemui goa-goa kecil yang dialiri air. Selain kolam permandian, terdapat akses menuju dalam goa yang dapat ditempuh sejauh 15 meter. Pada jarak 6 meter terdapat air terjun di sisi kanan jalur. Namun padamusim hujan, goa tidak dapat diakses karena ketinggian air mencapai dua meter dengan arus yang cukup deras.Sarana prasarana yang ditemukan sepanjang jalur antara lain warung yang menyediakan minuman dan makanan, areal parkir, gubuk pemberhentian dengan kondisi yang kurang layak ditempati, jembatan kayu diatas sungai kecil yang menghubungkan jalur dengan tempat peristirahatan, kamar mandi yang kondisinya kurang memadai, dan dua buah tempat peristirahatan di sekitar lokasi permandian. Sedangkan papan informasi yang terdapat di lokasi diantaranya papan nama objek wisata, papan peringatan (bahaya kebakaran), papan larangan (membuang puntung rokok, membuang sampah sembarangan), dan papan zonasi pemanfaatan kawasan Taman Nasional Bantimurung Bulusaraung. 


\section{Leang Bubbuka}

Leang ini merupakan goa pertama di Kawasan Biraeng yang lokasinya cukup dekat dengan jalan utama yakni sejauh 16 meter. Akses menuju lokasi ini cukup sulit karena jalan masuk tertutupi oleh pohon palem yang rapat dan tergenang air berlumpur.Ekosistem yang terdapat di sepanjang jalur adalah ekosistem hutan karst dengan dominansi pohon palem dengan ketinggian dua meter.Flora yang ditemukan sepanjang jalur pengamatan adalah pohon palem (Pandanus sp.) dan pohon pulai (Alstonia scholaris). Sedangkan fauna yang ditemukan hanya berada di dalam air yang tergenang seperti kerang dan siput air.Objek daya tarik utama yakni Leang Bubbuka yang merupakan salah satu goa prasejarah dengan didominasi batuan besar pada mulut goa di ketinggian 2,5 meter. Ketinggian mulut goa terbilang rendah yakni 0,5 meter dan dinding goa tersusun atas kerang-kerang yang menutupi langit-langit goa.Pada lokasi terdapat pondok peristirahatan dengan kondisi yang kurang layak. Papan informasi hanya berupa papan nama objek wisata milik Balai Pelestarian Peninggalan Purbakala Makassar Wilayah Kerja Provinsi Sulawesi Selatan, Sulawesi Utara dan Sulawesi Barat.

\section{Leang Caddia}

Leang ini berjarak 239 meter dari Leang Bubbuka. Posisi pintu gerbang berada tujuh meter dari tepi jalan. Untuk mencapai mulut goa perlu menaiki anak tangga sepanjang 39 meter dengan empat belokan. Kondisi tangga sepanjang jalur cukup aman karena terdapat pegangan di sisi kiri jalan. Namun pada musim hujan, jalanan yang terbuat dari semen menjadi licin karena berlubang dan terdapat banyak lumut.Ekosistem sepanjang jalur menuju objek utama yakni ekosistem hutan karst. Namun sepanjang jalur juga ditanami tanaman hias yang disusun dengan teratur.Flora yang ditemukan di sekitar objek ini sebagian besar tanaman hias yang sengaja ditanam untuk memperindah lokasi. Jenis yang ditanam antara lain tanaman Puring (Codiaeum variegatum) dan tanaman Palem (Pandanus sp.). Tumbuhan yang berkhasiat obat juga ditemukan di sekitar lokasi yakni tanaman obat Gandarusa.Objek daya tarik utama yakni Leang Caddia yang merupakan goa prasejarah dengan mulut goa berada diatas permukaan tanah setinggi tiga meter dan ketinggian jalan masuk hanya 0,5 meter.Terdapat dua buah pondok peristirahatan di lokasi ini. Pondok pertama berjarak 13 meter dari pintu gerbang sedangkan pondok kedua tepat di depan mulut goa. Kondisinya kurang memadai dan dari segi fisik kurang menarik. Sedangkan papan informasi yang tersedia berupa papan nama objek wisata, papan zonasi religi budaya \& sejarah kawasan Taman Nasional Bantimurung Bulusaraung, dan papan larangan membuang sampah di kawasan konservasi/lindung.

\section{Leang Lambuto}

Leang Lambuto merupakan goa berair dalam gugusan goa di kawasan Biraeng. Hal tersebut dikarenakan mulut goa sejajar dengan jalan utama atau kemiringan $0^{\circ}$. Sepanjang jalan masuk hingga ujung goa tertutup oleh air berlumpur setinggi mata kaki orang dewasa.Ekosistem sepanjang jalur adalah ekosistem karst yang didominasi tumbuhan rawa seperti palem berduri.Daya tarik utama terletak pada goa terbuka dengan lorong sepanjang delapan meter. Terdapat ornamen batu di langit goa yang terus meneteskan air yang berasal dari tumbuhan di sela-sela batuan.Terdapat pintu gerbang besi yang merupakan jalan masuk menuju goa. Kondisi pintu gerbang besi tidak terawat, berkarat, dan berlumut. Pagar kawat yang mengelilingi goa juga terputus. Papan informasi yang tersedia adalah papan nama objek wisata, papan zonasi 
religi budaya dan sejarah kawasan Taman Nasional Bantimurung Bulusaraung.

\section{Leang Lompoa}

Leang Lompoa merupakan leang yang berjarak 327 meter dari Leang Bubbuka. Akses menuju goa ini cukup baik dengan kondisi jalan beton dan bertangga, namun jalan agak licin dan berlumut. Di sepanjang sisi jalan terdapat parit kecil. Selain parit, terdapat kolam yang cukup besar dengan karst yang terlihat berwarna hijau karena ditutupi lumut. Panjang jalan beton hingga mencapai gerbang utama adalah 30 meter, sedangkan panjang jalur tangga adalah 69 meter dengan kemiringan mencapai $64^{\circ}$.Ekosistem sepanjang jalur adalah ekosistem hutan karst yang didominasi tumbuhan rawa seperti palem berduri. Sepanjang batuan karst juga ditumbuhi tumbuhan paku (Equisetum debile).Sedangkan fauna yang ditemukan adalah beberapa jenis ikan air tawar di kolam.

Daya tarik Leang Lompoa terletak pada artefak dalam goa yang menunjukan peninggalan prasejarah berupa sisa aktivitas manusia prasejarah antara lain sisa sampah dapur, artefak batu, dan lukisan dinding goa berupa gambar telapak tangan, gambar manusia dan hewan. Sampah dapur berupa cangkang mollusca dan rahang tulang binatang besar, sedangkan artefak batu yang ditemukan berupa alat serih bilah dan tatal. Ruangan dalam goa mudah diakses karena ketinggian langit-langit goa mencapai enammeter. Goa ini juga sering dikunjungi oleh peziarah dengan membawa sesajenkarena terdapat makam tua di mulut goa.Terdapat pondok peristirahatan yang berada tepat di sebelah kanan mulut goa dengan kondisi yang cukup terawat. Papan informasi yang tersedia antara lain papan nama objek wisata, papan interpretasi objek dan papan peringatan larangan merusak cagar budaya. Papan interpretasi objek wisata cukup rinci karena menjelaskan kondisi fisik dan peninggalan- peninggalan prasejarah yang terdapat dalam goa.

\section{Leang Kassi}

Leang ini berada 10 meter dari jalan utama. Akses menuju mulut goa dicapai dengan menaiki anak tangga sejauh \pm 20 meter. Kondisi jalan cukup licin karena banyak terdapat lumut dan tidak tersedia pegangan pada sisi tangga.Ekosistem yang berada di sepanjang jalur adalah ekosistem karst dan barisan tanaman hias yang cukup indah.Objek menarik dari Leang Kassi adalah gugusan batu yang menjulang tinggi dan lantai goa yang tertutup bongkahan batu besar. Terdapat sisa-sisa cangkang mollusca diantara batuan. Pada dinding goa terdapat lukisan prasejarah berupa gambaran manusia yang terlihat diukir dengan batu.Papan informasi yang ditemukan di lokasi ini cukup banyak seperti papan nama objek wisata, papan peringatan larangan merusak cagar budaya, papan kawasan Taman Nasional Bantimurung Bulusaraung dan papan interpretasi objek. Papan interpretasi objek wisata menjelaskan kondisi fisik dan temuan purbakala yang terdapat di leang ini. Terdapat pondok peristirahatan dengan kondisi yang cukup layak yang berada tepat di mulut goa.

\section{Leang Kajuara}

Jalur menuju pintu gerbang objek ini cukup panjang \pm 116 meter dengan lebar jalan setapak 0,8 meter. Kondisi jalan setapak terbuat dari beton dan agak berlumut sehingga licin pada saat musim hujan. Untuk mencapai mulut goa perlu menaiki anak tangga sepanjang 23,4 meter.Ekosistem yang terdapat di sepanjang jalur adalah ekosistem karst dengan dominansi tumbuhan rawa palem berduri. Terdapat pula ekosisitem sawah di sisi kiri jalur yang membentang luas.Flora yang banyak ditemukan sepanjang jalur adalah tumbuhan palem berduri, kelapa (Cocos 
nucifera), paku-pakuan (Equisetum debile), dan bambu(Bambusa sp.). Sedangkan fauna yang banyak ditemukan adalah kaki seribu.Daya tarik goa ini terdapat lukisan dinding goa berupa cap telapak tangan berwarna merah di langit-langit goa. Selain itu, terdapat peninggalan arkeologi berupa alat serpih dan beberapa tatal. Untuk memasuki area dalamgoaharus membungkukkan badan karena dinding goa cukup sempit untuk ukuran orang dewasa.Papan intrpretasi dan papan slogan terdapat di depan goa, namun kondisinya kurang baik. Papan interpretasi menginformasikan mengenai kondisi fisik goa dan temuan peninggalan purbakala. Terdapat pondok peristirahatan yang cukup memadai yang berada di tengah jalur sebelum memasuki anak tangga terakhir menuju mulut goa.

\section{Leang Pattenung}

Leang Pattenung merupakan rangkaian goa terakhir yang berada di jalur interpretasi. Leang ini berada tidak jauh jaraknya dengan Leang Kajuara. Kondisi jalan menuju masuk goa sudah di beton, namun licin jika hujan.Ekosistem Leang Pattenung merupakan ekosistem karst dengan dominasi tumbuhan palem berduri. Sementara di sebelah kanan jalur juga terdapat ekosistem sawah yang membentang luas.Flora yang terdapat di sepanjang jalur merupakan flora khas kawasan karst, berupa palem berduri, tumbuhan paku (Equisetum debile), kelapa (Cocos nucifera), dan puring (Codiaeum variegatum). Fauna yang terdapat di sepanjang jalur dapat ditemukan kupu-kupu, serangga, dan arthopoda. Memasuki mulut goa terdapat pintu gerbang kawat besi, namun kondisinya kurang baik. Selain itu permukaan jalan cukup becek dan lembap jika hujan. Goa ini terbuka dengan mulut yang lebar. Kondisi goa terdapat banyak ornamen stalaktit yang cukup menarik. Warna dinding goakehijauan karena terdapat lumut.Sarana dan prasarana yang ada di Leang Pattenung hanya papan interpretasi berupa papan nama dan papan larangan merusak cagar budaya.

Seorang perencana interpretasi menurut Ferry (1998) juga harus merencanakan media interpretasi untuk mencapai keberhasilan dalam menyampaikan pesan kepada pengunjung.Menurut analisis keinginan pengunjung, pengunjung lebih memilih media interpretasi dalam bentuk papan nama objek interpretasi, papan himbauan dan papan informasi berupa peta interpretasi. Kegiatan interpretasi di kawasan wisata ini mengarah pada jalur pemanduan sendiri atau self guided trails. Sehingga media yang tepat digunakan pada kawasan ini antara lain papan dan pal-pal interpretasi. Papan interpretasi seperti papan penunjuk arah, papan informasi, dan papan himbauan diletakkan di tempat yang strategis sesuai dengan fungsinya masing-masing. Papan lokasi objek diperlukan di persimpangan jalan utama. Papan informasi yang menjelaskan potensi dan sejarah objek diperlukan pada setiap objek karena dari delapan lokasi leang hanya tiga yang memiliki papan interpretasi dengan informasi yang cukup rinci. Papan himbauan dibutuhkan agar pengunjung menjaga perilakunya, seperti tidak merusak situs prasejarah dan tidak mencoreti dinding batuan (vandalisme). Penempatannya di lokasi yang disinyalir rawan terhadap kegiatan-kegiatan tersebut.

Sarana dan prasarana pendukung dibutuhkan untuk menunjang kegiatan interpretasi agar pesan yang disampaikan dapat dipahami pengunjung. Salah satu sarana yang menunjang adalah visitor center. Visitor center merupakan tempat yang menerangkan secarakeseluruhan keadaan sumberdaya fisik dan biologi kawasan wisata alam dan juga keadaan sosial budaya masyarakat sekitar. Menurut Ferry (1998) fungsi dari visitor center untuk membatu pengunjung dalam menikmati kunjungan di suatu area sumberdaya. Dalam visitor center terdapat 
sejarah kawasan, tema kawasan dan meyajikan elemen cerita terbaik di kawasan tersebut.Posisi perencanaan visitor center ditempatkan di kantor Resort Minasa Te'ne Taman Nasional Bantimurung Bulusaraung. Materi yang perlu disajikan adalah peta kawasan wisata, peta lokasi sarana dan prasarana, peta jalur interpretasi, maket kawasan, panil sejarah dan foto-foto objek wisata, brosur dan buku panduan kegiatan interpretasi di kawasan wisata Resort Minasa Te'ne. Selain itu terdapat outlet yang menjual pernak-pernik serta cendera mata khas kawasan seperti kaos, gantungan kunci, makanan serta minuman khas buatan masyarakat sekitar.

\section{B. Rencana Kegiatan}

Rencana kegiatan ditujukan baik kepada pengelola, kawasan, maupun pengunjung. Rencana ini mencakup hal-hal yang perlu dilakukan guna menunjang kegiatan interpretasi di kawasan. Rencana kegiatan bagi pengelola antara lain melakukan monitoring potensi sumberdaya yang ada di kawasan resort Minasa Te'ne. Monitoring dilakukan terhadap objek-objek yang memiliki potensi untuk dikembangkan pengelola melalui kegiatan penelitian mengenai sumberdaya. Kemudian melakukan pemeliharaan dan perbaikan bangunan serta sarana dan prasarana. Pemeliharaan objek dilakukan sebulan sekali dan perbaikan dilakukan secara kondisional dengan mencegah segala macam vandalisme yang dapat terjadi. Perawatan dan perbaikan dilakukan dengan mengontrol media meliputi sarana dan prasarana, seperti papan interpretasi, penunjuk arah, tanda peringatan, dan shelter. Selain mengontrol kondisi fisik kawasan, kegiatan peningkatan kapasitas sumberdaya manusia juga perlu dilakukan melalui kegiatan pelatihan kepada para pekerja kawasan wisata mengenai kegiatan interpretasi alam. Dengan kegiatan seperti pemberian motivasi kerja dan seminar peningkatan kualitas kerja.

Perencanaan terhadap kawasan dilakukan untuk mendukung kegiatan interpretasi. Kegiatan yang dapat dilakukan antara lain membangun visitor center di Kantor Resort Minasa Te'ne Taman Nasional Bantimurung Bulusaraung yang akan menjadi pusat dari jalur interpretasi pada kawasan yang direncanakan. Di dalamnya terdapat layar ukuran besar yang menayangkan sejarah mengenai objek-objek wisata yang berada di kawasan resort Minasa Te'ne. Selain visitor center, diperlukan juga historical gallery yang didalamnya terdapat barang-barang peninggalan dan gambar lukisan prasejarah beserta sejarah penemuannya.Membuat area mapyang diletakkan di visitor center. Peta lokasi diletakkan pada tempat sedemikian rupa sehingga terhindar dari hujan dan cukup rendah sehingga pengunjung dapat membacanya. Entrance dan directional signs ditempatkan pada lokasi yang menarik pengunjung, diletakkan pada tempat yang tinggi, berukuran besar, dekat dengan arah yang ditunjukkan, dan dapat dibaca dari dua arah. Membuat papan interpretasi mengenai kondisi fisik dan sejarah objek yang ditempatkan pada setiap lokasi objek. Papan interpretasi dibuat semenarik mungkin dengan mengurangi tulisan yang panjang dengan desain visual dan kalimat yang memancing rasa ingin tahu pengunjung.

Rencana kegiatan pengunjung dilakukan dalam rangka mendukung kegiatan interpretasi. Tema dari kegiatan ini adalah Wisata Alam dan Sejarah Minasa Te'ne, maka kegiatan yang direncanakan adalah mengunjungi wisata alam permandian alami dengan panorama mulut goa dan ekosistem karst serta mengunjungi wisata goa prasejarah. Pengunjung permandian Leang Londrong selama ini hanya mendatangi lokasi ini untuk berendam atau mandi. Namun terdapat potensi lain yang menarik untuk dinikmati 
pengunjung. Sepanjang jalan setapak menuju Leang Londrong terdapat barisan batuan karst yang indah. Selain itu terdapat pula tumbuhan yang banyak dihinggapi kupu-kupu karena merupakan pakan yang disukainya seperti Sirih hutan dan Asoka hutan. Pada lokasi permandian, terdapat mulut goa tempat keluarnya air. Pengunjung yang ingin menyaksikan ornamen dalam goa dapat memasuki mulut goa dengan menaiki batuan dan menyusuri tepian goa dengan hati-hati. Terdapat air terjun pada jarak \pm enam meter dari mulut goa. Kegiatan kedua yakni mengunjungi wisata goa prasejarah. Kelurahan Biraeng memiliki barisan batuankarst yang panjang, maka dari itu di kawasan ini banyak ditemukan goa. Terdapat tujuh goa prasejarah dengan jarak yang cukup berdekatan. Sebagian besar goa sudah memiliki akses yang baik dan aman, namun sebagian kecilnya sulit dicapai karena tergenang air pada musim hujan. Pengunjung dapat mengunjungi goa dengan berurutan karena memudahkan akses. Panjang jalur interpretasi sepanjang barisan goa ini $\pm 1,5 \mathrm{~km}$ dan membutuhkan waktu 1,5 jam dengan berjalan kaki.Pengunjung dapat ditemani oleh pelaksana interpretasi/pemandu untuk menerangkan objek prasejarah yang ditemui di lokasi atau dapat mengunjunginya sendiri (self guide). Pengunjung yang datang tanpa ditemani interpreter dapat memahami objek dengan bantuan media interpretasi berupa papan interpretasi atau mengunjungi visitor center.

\section{Rencana Penugasan}

Pengelolaan pariwisata alam di TN Bantimurung Bulusaraung belum terkelola sesuai dengan peraturan perundangan yang berlaku. Berdasarkan peraturan perundangan yang berlaku, pengelolaan wisata di kawasan konservasi tidak dapat dilakukan langsung oleh Pemerintah daerah, namun ijin pengelolaan pariwisata alam dapat diberikan kepada BUMD/BUMN, koperasi, perseorangan atau swasta.Objek wisata alam permandian Leang Londrong saat ini dikelola oleh desa setempat yakni Dusun Leang Londrong Desa Panaikang. Sedangkan objek wisata prasejarah seharusnya dikelola oleh Balai Pelestarian Peninggalan Purbakala Makassar Wilayah Kerja Provinsi Sulawesi Selatan, Sulawesi Utara dan Sulawesi Barat. Namun dari kedua pengelolaan tersebut belum ada yang berhubungan dengan kegiatan interpretasi alam. Maka diperlukan suatu organisasi khusus kegiatan interpretasi alam. Unsur pokok yang harus ada adalah pemimpin interpretasi, perencana interpretasi dan pelaksana interpretasi.

Tugas utama dari pemimpin interpretasi adalah bertanggung jawab atas semua kegiatan interpretasi yang ada di kawasan wisata resort Minasa Te'ne. Pemimpin merupakan seorang yang memiliki pengalaman dalam kegiatan interpretasi. Kantornya terdapat di wisma cinta alam karena merupakan pusat informasi keseluruhan kawasan sehingga mempermudah dalam kegiatan penugasannya. Perencana interpretasi bertugas merencanakan kegiatan dan menentukan media interpretasi apa saja yang digunakan dan apa isi dari media tersebut. Serta menentukan kondisi objek interpretasi sehingga perencana sebaiknya berupa tim yang terdiri dari ahli interpretasi, ahli goa, ahli sejarah, dan arsitektur lansekap.Sedangkan pelaksana interpretasi bertugas untuk mengkomunikasikan objek kepada pengunjung sehingga pengunjung memahami kegiatan interpretasi di kawasan wisata resort Minasa Te'ne. Pelaksana yang dibutuhkan yakni masyarakat yang memahami sejarah objek dan kawasan sekitarnya. Pemandu harus menarik perhatian pengunjung yang didampinginya, memberikan pengalaman yang menyenangkan dalam perjalanan, membuat pengunjung merasa senang, menguasai sasaran berdasarkan selera 
pengunjung, memperhatkan latar belakang pengunjung dan memiliki pengetahuan yang luas terkait kawasan yang diinterpretasikannya.

\section{KESIMPULAN DAN SARAN}

Pengembangan wisata alam di taman nasional perlu dilakukan dalam upaya mengenalkan potensi sumberdaya terhadap masyarakat luas. Pengembangan ini diarahkan kepada kegiatan yang dapat meningkatkan pengetahuan pengunjung dan nilai tambah objek wisata. Perencanaan interpretasi alam di kawasan wisata Resort Minasa Te'ne Taman Nasional Bantimurung Bulusaraung dilakukan dengan menyusun rencana yang terdiri atas rencana satuan, kawasan, dan penugasan. Kegiatan ini selain memudahkan pengunjung dalam mengakses sumberdaya juga sebagai sarana pendidikan bagi pengunjung sehingga kegiatan wisata jauh lebih bermanfaat.

\section{DAFTAR PUSTAKA}

Balai Taman Nasional Bantimurung Bulusaraung. (2011).Identifikasi Potensi Jasa Lingkungan. Maros.

Carr, A. (2004). Mountain Places, Cultural Spaces: The Interpretation of Culturally Significant Landscapes. Journal of Sustainable Tourism 12(5), 432-459.

Dinas Kebudayaan dan Pariwisata Kabupaten Pangkajene dan kepulauan. (2012). Pangkep Unik dan Eksotik. Pangkajene.
Domroese, MC., EJ. Sterling. (1999). Interpreting Biodiversity: A Manual forEnvironmentalEducators in the Tropics. Center for Biodiversity and Conservation, American Museum of Natural History. New York, USA.

Ferry, H. (1998). Planning for Interpretation and Visitor Experience. WestVirginia.

Heriyaningtyas, E. (2009). Perencanaan interpretasi kawasan wisata alam lereng pegunungan muria Kabupaten Kudus Jawa Tengah. [Skripsi]. Fakultas Kehutanan Institut Pertanian Bogor. Bogor.

McArthur, S. (2005). Interpretation Plan for the Conservation and Adaptive re-use Of the North Head Quarantine Station. Mawland Construction Pty Ltd for .Australia.

Satyatama, T. (2008). Perencanaan beberapa jalur interpretasi alam di Taman Nasional Gunung Merbabu Jawa Tengah dengan menggunakan sistem informasi geografis. [Tesis]. Sekolah Pascasarjana Institut Pertanian Bogor. Bogor.

Sharpe, GW. (1982). Interpreting the Environment (2nd edition). John Willey \&Sons, Inc.

Tim FPS Karst Pangkep. (2013). Laporan Akhir Perencanaan Pengembangan Kawasan Karst Pangkep sebagai Daya Tarik Wisata Bumi Kabupaten Pangkajene dan Kepulauan Provinsi Sulawesi Selatan. Manajemen Destinasi Wisata. Jurusan Kepariwisataan. Sekolah Tinggi Pariwisata Bandung. 